\title{
Aspects of Humoral Immunity in a Prospective Study of Type I (Insulin-Dependent) Diabetic Subjects Treated with Insulins of Different Purity
}

\author{
M. Iavicoli, L. Ventriglia, U. Di Mario, C. Galfo and D. Andreani \\ I Cattedra di Medicina Costituzionale ed Endocrinologia, Università degli Studi di Roma, Rome, Italy
}

\begin{abstract}
Summary. In 41 Type 1 (insulin-dependent) diabetic patients, islet cell antibodies, anti-insulin antibodies, and immune complexes measured by two different methods (the C1q solid phase assay and the conglutinin binding test) were studied at diagnosis, and the influence of treatment with insulins of different purity was investigated during the first year of treatment. Twenty subjects were treated with conventional insulins (group 1) while 21 were treated with monocomponent porcine insulins (group 2). The prevalence of islet cell antibodies significantly decreased during the 12-month study period in the 41 patients. From the first month anti-insulin antibodies were always significantly higher in group 1 than in group 2 . At diagnosis the prevalence of both types of immune complexes in the 41 patients was higher than in normal subjects. The im-
\end{abstract}

mune complexes measured by the C1q solid phase method showed a significant and progressive reduction during the follow-up period, whereas the immune complexes assayed by conglutinin showed no significant variation in the same period. The presence of $\mathrm{C} 1 \mathrm{q}$ immune complexes was found to correlate with the occurrence of islet cell antibodies both at diagnosis and during the follow-up period. The presence of conglutinin immune complexes, on the other hand, tended to parallel the increase of anti-insulin antibody levels.

Key words: Type 1 diabetes, anti-insulin antibodies, islet cell antibodies, immune complexes, C1q solid phase assay, conglutinin binding test, monocomponent insulins.
Islet cell antibodies, anti-insulin antibodies and immune complexes have been demonstrated in the sera of diabetic subjects. Islet cell antibodies have been found in Type 1 (insulin-dependent) diabetic patients at diagnosis and in non-diabetic patients with other autoimmune diseases. The role of these antibodies in the pathogenesis of Type 1 diabetes remains to be elucidated [1-3]. Anti-insulin antibodies are present in most insulin-treated diabetic patients. It has been established that anti-insulin antibodies may play a role in the transient complications of insulin treatment (i.e. allergic reactions, insulin resistance, etc.), whereas no influence on late diabetic complications has yet been demonstrated [4-9].

It has been suggested that the presence of islet cell and anti-insulin antibodies in the circulation may reflect the presence of circulating immune complexes $[10$, 11]. Circulating immune complexes have been described in a large percentage of Type I diabetic patients at the time of diagnosis [12] and in some cases with severe complications [13]. Detection methods based upon different principles have also revealed the presence of heterogeneous populations of immune complexes [14,
15]. A correlation was recognized in some of these studies between immune complexes detected by the solid phase C1q binding test and the presence of islet cell antibodies [16], whilst in others a correlation appeared to exist between immune complexes detected by conglutinin binding assay and insulin treatment [17].

The present investigation was carried out in a group of patients at the time of clinical diagnosis of Type I diabetes. These patients were treated with either conventional insulin or monocomponent insulin and were observed at regular intervals for one year.

The aim of the present study was to attempt to correlate circulating immune complexes (detected by $\mathrm{C} 1 \mathrm{q}$ and conglutinin) and the presence of islet cell and antiinsulin antibodies, bearing in mind the type and duration of the diabetes and antigenicity of the insulin used in the treatment.

\section{Patients and Methods}

Forty-one newly diagnosed Type I diabetic patients, with age at onset $<30$ years, were included in the study before insulin treatment was started. Twenty of these patients (12 males and eight females, mean 
Table 1. Anti-insulin antibodies in Type 1 diabetic patients at diagnosis and during 1 year's treatment

\begin{tabular}{lllll}
\hline & \multicolumn{4}{l}{ Duration of treatment (months) } \\
\cline { 2 - 5 } & 1 & 3 & 6 & 12 \\
\hline Group 1 & $0.8 \pm 0.8^{\mathrm{a}}$ & $1.7 \pm 1.5^{\mathrm{b}}$ & $1.8 \pm 1.9^{\mathrm{b}}$ & $1.9 \pm 1.3^{\mathrm{b}}$ \\
Group 2 & $0.08 \pm 0.11$ & $0.3 \pm 0.4$ & $0.3 \pm 0.5$ & $0.2 \pm 0.3$ \\
\hline
\end{tabular}

Results are presented as mean $\pm \mathrm{SD} ;{ }^{\mathrm{a}} p<0.02 ;{ }^{b} p<0.001$

Table 2. Immune complexes assayed with C1q solid phase method and with conglutinin binding test in Type 1 diabetic patients at diagnosis and during 1 year's treatment

\begin{tabular}{lccccc}
\hline \multicolumn{5}{c}{ Duration of treatment (months) } \\
\cline { 2 - 6 } & 0 & 1 & 3 & 6 & 12 \\
\hline \multicolumn{7}{c}{ Clq solid phase } & method \\
$\quad$ Group 1 & $9 / 20$ & $5 / 17$ & $4 / 16$ & $2 / 18$ & $3 / 20$ \\
Group 2 & $10 / 21$ & $6 / 19$ & $3 / 15$ & $3 / 19$ & $2 / 20$ \\
Total & $19 / 41$ & $11 / 36$ & $7 / 31$ & $5 / 37$ & $5 / 40$ \\
& & & $p<0.01$ & & \\
Conglutin binding test & & & & \\
Group 1 & $6 / 20$ & $6 / 17$ & $6 / 17$ & $7 / 19$ & $8 / 20$ \\
Group 2 & $6 / 21$ & $4 / 18$ & $5 / 18$ & $7 / 18$ & $4 / 20$ \\
Total & $12 / 41$ & $10 / 35$ & $11 / 35$ & $14 / 37$ & $12 / 40$ \\
\hline
\end{tabular}

Results are presented as positive/total subjects

age 9 years, range 5-11 years) were treated with conventional insulins (group 1), whereas 21 (15 males and six females, mean age 13 years, range $8-22$ years) were treated with monocomponent porcine insulins (group 2). Patients were randomly assigned to each group. Blood samples were collected at diagnosis and 1, 3,6 and 12 months later in all patients.

A series of 189 blood donors was also studied to determine the normal range of the immune complex assays. Islet cell antibodies were assayed by indirect immunofluorescence on cryostat sections of blood group 0 human pancreas. The presence of islet cell antibodies was evaluated by two independent observers using a Leitz Dialux microscope.

Anti-insulin antibodies, evaluated as insulin binding capacity, were measured by an immunoelectrophoretic method [18]; the sensitivity of the method is $0.05 \mathrm{mU} / \mathrm{ml}$, the interassay variation $3 \%$.

Immune complexes were determined by the C1q solid phase method according to Hay et al. [19] and by the conglutinin binding test according to Casali et al. [20]. The characteristics of the methods are described elsewhere [21].

The $\chi^{2}$ test, Fisher's exact test, Cox's test, Student's t-test for independent variables and the binomial test were used for statistical evaluation of the results.

\section{Results}

Islet cell antibodies were detected in 19 of the 41 diabetic patients at diagnosis (46\%). During the follow-up period their prevalence decreased progressively to $10 \%$ after 12 months. This decrease was statistically significant $(p<0.001)$. No difference in occurrence of islet cell antibody was found between the two groups of patients. Anti-insulin antibodies were detectable after the first month of treatment, being significantly higher in

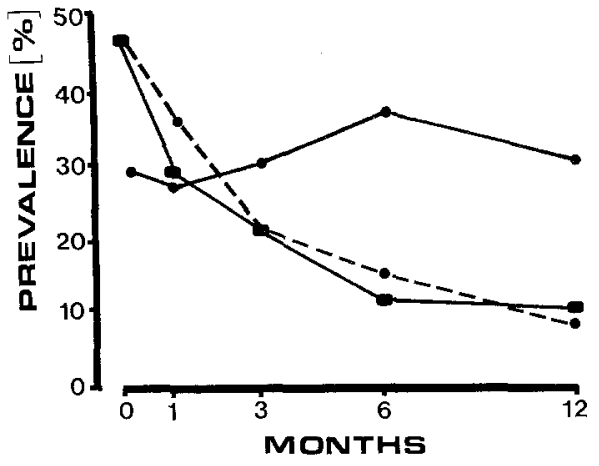

Fig. 1. Prevalence of immune complexes assayed with $\mathrm{C} 1 \mathrm{q}$ solid phase method $(\square-\square)$ and with conglutinin binding test $(\bullet-\bullet)$ and of islet cell antibodies (--- $\bullet$ ) in 41 Type 1 diabetic patients at diagnosis and during 1 year follow-up

group 1 than in group 2 at each stage of follow-up (Table 1).

C1q immune complexes were present in 19 of the 41 diabetic patients at diagnosis (46\%) and progressively decreased thereafter (Table 2). Prevalence at 12 months' follow-up was $12 \%$. This decrease was statistically significant $(p<0.01)$. No difference was found between groups 1 and 2. Conglutinin immune complexes were present in 12 of the 41 diabetic patients at diagnosis $(29 \%)$, prevalence varying during follow-up from a minimum of $26 \%$ to a maximum of $38 \%$ (NS). Although at 12 months the prevalence was $40 \%$ in group 1 and $20 \%$ in group 2 , the differences between the two groups were not significant.

Islet cell antibodies and $\mathrm{C} 1 \mathrm{q}$ immune complexes showed similar decreases in frequency from diagnosis to 12 months in all patients together and in the two groups examined separately. C1q immune complexes were detected in $58 \%$ of the 19 islet-cell-antibody-positive subjects at diagnosis. The agreement between the two tests (both positive and negative) was significant (1 month $p<0.05,6$ months $p<0.001,12$ months $p<$ 0.001 ).

Islet cell antibodies and conglutinin immune complexes showed different profiles during follow-up (Fig.1). Analysis of the relationship between these two immunological factors demonstrated a difference in prevalence at diagnosis ( $46 \%$ versus $29 \%$ ), and only four out of the 19 islet-cell-antibody-positive subjects also showed conglutinin immune complexes. No significant agreement was found between the two tests.

No significant correlation was found between $\mathrm{C} 1 \mathrm{q}$ immune complexes and anti-insulin antibodies, either in the 41 diabetic patients or in groups 1 and 2 considered separately. The presence of conglutinin immune complexes, on the other hand, showed a tendency to parallel the increase in anti-insulin antibody levels in the 41 diabetic patients $(p<0.001)$. This trend was still present when the two groups were examined separately $(p<0.001)$. However, whereas in group 1 maximum 
prevalence of conglutinin immune complexes (85\%) was reached when anti-insulin antibody levels were above $2 \mathrm{mU} / \mathrm{ml}(p<0.002)$, the maximum $(75 \%)$ in group 2 was reached at lower anti-insulin antibody levels $(0.5-2 \mathrm{mU} / \mathrm{ml})(p<0.002)$.

\section{Discussion}

These results demonstrate a correlation between $\mathrm{C} 1 \mathrm{q}$ immune complexes and islet cell antibodies, and between conglutinin immune complexes and anti-insulin antibodies, whereas no correlation was found between C1q immune complexes and anti-insulin antibodies or between conglutinin immune complexes and islet cell antibodies. Furthermore, C1q and conglutinin probably detect different populations of immune complexes.

It is possible that islet cell antibodies and C1q immune complexes are present at the time of diagnosis independently of each other and are different expressions of the immune response to the same aetiological agent; on the other hand, the correlation between C1q immune complexes and islet cell antibodies observed in the present study suggests that the islet cell antibodies might circulate in the form of soluble complexes bound to antigens of islet origin. In this case immune complexes detected by Clq assay at diagnosis may be a reflection of such a phenomenon.

Of interest in the present study is the relationship observed between conglutinin-immune complexes and insulin binding capacity. We have demonstrated previously a relationship between this type of immune complex and insulin treatment [17]: these complexes were significantly more frequent in patients treated with insulin than in others [21]. The present data, showing the existence of a significant trend in the prevalence of circulating conglutinin-immune complexes with increasing levels of insulin binding capacity, appear to suggest that the conglutinin method detects insulin-anti-insulin complexes present in diabetic patients following treatment. On the other hand, assay of immune complexes using conglutinin could be affected by the anti-insulin antibodies and by the aggregates of these antibodies.

It is more difficult to offer an explanation for the observation that the relationship between conglutinin-immune complexes and the levels of insulin binding capacity in patients treated with conventional insulins (group 1) differs from that in patients treated with monocomponent insulins (group 2). It would, in fact, appear that while the former tend to produce immune complexes at high levels of insulin binding capacity, the latter form these complexes at low or medium levels of insulin binding capacity.

This finding may be due to the difference in immunogenicity of the two types of insulin. Even though because of their purity, monocomponent insulins produce low overall levels of insulin-binding capacity, the antibodies induced have a relatively high affinity for insulin. In contrast, conventional insulins, which contain extractive polypeptides with a greater molecular weight and immunogenic capacity than pure insulin, tend to produce larger families of antibodies only some of which display marked affinity for insulin, even though all may be detectable as insulin binding capacity by Christiansen's method $[4,8]$.

It is thus possible that for the same insulin-binding capacity level, patients treated with monocomponent insulin produce a larger quantity of specific complexes than those using conventional insulins.

In conclusion, the present findings confirm the presence of circulating immune complexes in patients with Type 1 diabetes mellitus, some of which may be related to factors present at diagnosis, others to anti-insulin antibodies.

On the other hand conglutinin-immune complexes might provide a useful method with which to follow the pathological events associated with circulating anti-insulin antibodies.

Acknowledgements. We are grateful to Dr. L.Heding for insulin supply and to Mr. C. Tiberti for his technical assistance. This work was supported in part by grant no.81.00343.83 from the National Research Council, Italy.

\section{References}

1. Lendrum R, Walker G, Gamble DR (1975) Islet-cell antibodies in juvenile diabetes mellitus of recent onset. Lancet 1: 880-882

2. Bottazzo GF, Pujol-Borrel R, Doniach D (1981) Humoral and cellular immunity in diabetes mellitus. Clin Immunol Allergy 1: 139-159

3. Lernmark A, Baekkeskov S (1981) Islet cell antibodies. Theoretical and practical implications. Diabetologia 21: 431-435

4. Berson SA, Yalow RS (1959) Quantitative aspects of the reaction between insulin and insulin antibody. J Clin Invest 38: 1996-2016

5. Andreani D, Iavicoli M, Tamburrano G, Menzinger G (1974) Comparative trials with monocomponent (MC) and monospecies (MS) pork insulins in the treatment of diabetes mellitus. Influence on antibody levels, on insulin requirement and some complications. Horm Metab Res 6: 447-454

6. Andersen $O O$ (1976) Anti-insulin antibodies and late diabetic complications. Acta Endocrinol (Kbh) 83: 329-333

7. Werner AV, Larsen HW (1969) Immunohistological studies of human diabetic and non diabetic eyes. I Fluorescent labeling of insulin and anti-insulin antibodies. Acta Ophthalmol (Kbh) 47: 937-945

8. Wehner H, Huber H, Kronemberg KH (1973) The glomerular basement membrane of the rabbit kidney on long term treatment with heterologous insulin preparations of different pituitary. Diabetologia 9: 255-265

9. Kurtz AB, Nabarro JDN (1980) Circulating insulin binding antibodies. Diabetologia 19: 329-334

10. Jayarao K, Page Faulk W, Karam H, Grodsky GM, Forsham PH (1974) Evidence in support of the concept of immune complexes disease in insulin treated diabetics. In: Bastenie PA, Gepts W (eds) Immunity and autoimmunity in diabetes mellitus. Excerpta Medica, Amsterdam, pp 255-263

11. Følling I (1976) Insulin anti-insulin complexes. Acta Endocrinol 83 (Suppl 205) 199-201

12. Irvine WJ, Di Mario U, Guy K, Feek CM, Gray RS, Duncan LJP (1978) Immune complexes in newly diagnosed insulin dependent (type I) diabetics. J Clin Lab Immunol 1: 183-186 
13. Irvine WJ, Di Mario U, Guy K, Iavicoli M, Pozzilli P, Lumbroso B, Andreani D (1978) Immune complexes and diabetic microangiopathy. J Clin Lab Immunol 1: 187-191

14. Di Mario U, Iavicoli M, Andreani D (1980) Circulating immune complexes in diabetes. Diabetologia 19: 89-92

15. Di Mario U, Iavicoli M, Ventriglia L, Galfo C, Bellagamba C, Trionfera G, Cicconetti C, Andreani D (1979) Immune complexes, microangiopathy and metabolic control in diabetes. In: Waldhäusl WK (ed) Diabetes 1979, Excerpta Medica, Amsterdam, pp 379-382

16. Irvine WJ, Di Mario U, Guy K, Borsey DR (1980) Immune complexes in Type I diabetics with persistent islet cell antibodies. J. Clin Lab Immunol 4: 87-89

17. Iavicoli M, Guy K, Ventriglia L, Galfo C, Di Nichilo M, Di Mario U, Andreani D (1981) Correlazione tra gli immunocomplessi circolanti ed il trattamento insulinico nel diabete mellito. J Endocrinol Invest 4 (Suppl 1): 317-319

18. Christiansen $\mathrm{AH}$ (1970) A new method for determination of insulin binding immunoglobulins in insulin treated diabetic patients. Horm Metab Res 2: 186-190

19. Hay FC, Nineham LJ, Roitt IM (1976) Routine assay for the de- tection of immune complexes of known immunoglobulin class using solid phase C1q. Clin Exp Immunol 24: 396-400

20. Casali P, Bossus A, Carpentier NA, Lambert PH (1977) Solid phase enzyme immunoassay or radioimmunoassay for the detection of immune complexes based on their recognition by conglutinin-conglutinin-binding test. A comparative study with ${ }^{125}$ I-labelled C1q binding and Raji cell Ria test. Clin Exp Immunol 29: $342-354$

21. Andreani D, Di Mario U, Galfo C, Ventriglia L, Iavicoli M (1982) Immune complexes in diabetes mellitus: evaluation by two different methods. Acta Endocrinol (Kbh) 99: 239-244

Received: 15 September 1981

and in revised form: 15 September 1982

Dr. M. Iavicoli

II Clinica Medica

Policlinico Umberto 1

00161 Rome

Italy 